\title{
Critical value of soil Olsen-P for potato production systems in volcanic soils of Chile
}

\author{
Patricio Sandaña*,Sandra Orena, José Santos Rojas, Julio Kalazich, Marco Uribe
}

Instituto de Investigaciones Agropecuarias, INIA-Remehue, Ruta 5, km 8 Norte, Osorno, Chile. *Corresponding author: patricio.sandana@inia.cl

\begin{abstract}
The critical value of soil Olsen-P (mg Olsen-P kg-1) is the value of soil Olsen-P above which the probability of crop response to $\mathrm{P}$ fertilization is small or null. The aim of the present study was to determine the critical value of soil Olsen$\mathrm{P}$ for potato tuber yield in volcanic soils. The data used in this study were taken from 41 experiments of $\mathrm{P}$ fertilization conducted in southern Chile from 1977 to 2015 by the National Potato Center at the Instituto de Investigaciones Agropecuarias (INIA). To identify the critical values of soil Olsen-P, relationships between relative yields and initial soil POlsen were assessed using three models (linear-plateau, boundary and Mitscherlich function). Across experiments, the average fresh tuber yield was $41.9 \mathrm{Mg} \mathrm{ha}^{-1}$ and varied between 4 and $89 \mathrm{Mg} \mathrm{ha}^{-1}$. Fresh tuber yield decreased up to $92 \%$ by $\mathrm{P}$ deficiency; however, yield reduction was concentrated between 20 and $40 \%$. The critical Olsen $\mathrm{P}$ values determined were 41, 33 and $11 \mathrm{mg}$ Olsen-P kg-1 obtained $(P<0.01)$ with linear-plateau, boundary function and Mitscherlich function, respectively. However, linear-plateau and Mitscherlich functions showed lower coefficient of determinations $\left(R^{2}=0.23-0.31\right)$ than the boundary function $\left(R^{2}=0.97\right)$. Therefore, we suggest that the critical Olsen-P value of $33 \mathrm{mg}$ $\mathrm{P} \mathrm{kg}^{-1}$ determined with the boundary function is more appropriate for potato growers than the critical value determined with the other models. This information will be valuable for optimizing strategies for $\mathrm{P}$ fertilizer management in potato production systems aimed at achieving optimal crop yield and minimizing potential environmental risk.
\end{abstract}

Keywords: Tuber yield, Phosphorus deficiency, P-Olsen, P supply, P rate.

\section{Introduction}

Phosphorus $(\mathrm{P})$ has been considered a major factor limiting crop productivity, and large amounts of $\mathrm{P}$ have been applied to soils since the Green Revolution to sustain production of agricultural systems (Tilman et al., 2001, 2002). Relative to nitrogen and potassium, the recovery of $\mathrm{P}$ fertilizers by crop plants is usually very low due to the high capacity of soils to fix P (Manske et al., 2001; Balemi and
Negisho, 2012). Potato is particularly sensitive to P-deficient soils, indicating a low P uptake efficiency (Sandaña, 2016) and, therefore, P fertilization is a critical component of profitable potato production as many soils lack sufficient $\mathrm{P}$ to optimize crop growth (Rosen et al., 2014; Hopkins et al., 2014; Thornton et al., 2014; Sandaña and Kalazich, 2015; Sandaña, 2016). However, there 
are some trends likely to drive the effort to improve P management in this crop, since i) phosphate rock will be much less available (Cordell et al., 2009), ii) $\mathrm{P}$ prices are likely to increase as it becomes more difficult to extract from phosphate rock (Elser and Bennett, 2011), and iii) the environmental concern regarding the effect of $\mathrm{P}$ fertilization given that repeated applications of $\mathrm{P}$ fertilizers has a direct negative impact on surface waters that influence the functioning of ecosystems (Tilman et al., 2001). Thus, to realize a sustainable $\mathrm{P}$ use in agriculture, it is important to optimize soil P management to achieve optimal crop yield, minimize potential adverse effects on environment and limit the accumulation of soil P to certain target levels (Rowe et al., 2016). Therefore, for a better P management, determining the critical value of soil Olsen-P to optimize $P$ fertilization in potato crops is crucial.

The critical value of soil Olsen-P is the value of soil Olsen-P above which the probability of crop response to $\mathrm{P}$ fertilization is small or null (Tang et al., 2009; Bai et al., 2013; Sucunza et al., 2018). Critical values of soil Olsen$\mathrm{P}$ differ among crops because of different $\mathrm{P}$ requirements and $\mathrm{P}$ uptake efficiencies (Colomb et al., 2007; Sandaña and Pinochet, 2016). The critical values of soil Olsen-P range from 3.9 to $15 \mathrm{mg} \mathrm{kg}^{-1}$ for maize (Mallarino and Atia, 2005; Colomb et al., 2007) and from 4.9 to $20 \mathrm{mg}$ $\mathrm{kg}^{-1}$ for winter wheat (Johnston et al., 1986; Bollons and Barraclough, 1999; Colomb et al., 2007). For potato, Maier et al. (1989) determined a critical value of Olsen-P of $17 \mathrm{mg} \mathrm{P} \mathrm{kg}^{-1}$, whereas Johnston et al. (1986) concluded that potato yield generally plateaued when soil Olsen-P test reached $25 \mathrm{mg} \mathrm{P} \mathrm{kg}^{-1}$, but this value varied between 10 and $54 \mathrm{mg} \mathrm{P} \mathrm{kg}^{-1}$ across years. The critical values of soil Olsen-P differ among sites because of differences in soil properties, with the soil texture being an important component (Redulla et al., 2002; Johnston et al., 2013). In addition, critical values of soil Olsen-P vary according to statistical model used for its determination. The statistical models such as the Mitscherlich, linear-linear, and linear-plateau are among the most used to determine criti- cal values. (Colomb et al., 2007; Tang et al., 2009; Bai et al., 2013; Sucunza et al., 2018). However, the linearlinear and linear-plateau methods do not require an arbitrarily defined relative yield level (i.e.: $95 \%$ maximum attainable yield) to define the critical value of soil $\mathrm{P}$ test as required in the Mitscherlich model (Colomb et al., 2007; Tang et al., 2009).

To our knowledge there is no information about the critical value of soil Olsen-P for potato crops cultivated in volcanic soils (Andisols) such as those in southern Chile, where most potato crops are planted (Haverkort et al., 2014). Andisol soils, derived from volcanic materials, are characterized by their high P retention capacities, this being the main constraint of crop productivity in these soils (Valle et al., 2015). Although Andisols are very productive, they are often deficient in P; therefore, large doses of $\mathrm{P}$ fertilizers should be applied to maximize yields (Dahlgren et al., 2004; Sandaña and Pinochet, 2014). However, this is in contrast with the global challenge of increasing crop productivity with a lower input of $\mathrm{P}$ fertilizers (Gregory and George, 2011, Thornton et al., 2014). Therefore, the aim of the present study was to determine the critical value of soil Olsen-P for potato tuber yield in volcanic soils in southern Chile.

\section{Materials and methods}

\subsection{Sites, experiments and experimental design}

The data used in this study were taken from 41 experiments conducted in southern Chile from 1977 to 2015 by the National Potato Center at the Instituto de Investigaciones Agropecuarias (INIA), Osorno, Chile. Experiments were performed in Andisol soils in different environments from Chillán $\left(36^{\circ} 36^{\prime} 47 \mathrm{~S} ; 7^{\circ} 05^{\prime} 54 \mathrm{~W}\right)$ to Castro $\left(42^{\circ} 28^{\prime} 44 \mathrm{~S} ; 7^{\circ} 45^{\prime} 58 \mathrm{~W}\right)$ on Chiloe Island (Figure 1). $80 \%$ of the total potato area is cultivated from the regions of Maule to Los Lagos (ODEPA, 2017). Most potatoes are cultivated from October to March. However, early (September) and late (November) planting 
dates are also found in this zone. The data set comprised experiments where the yield responses of one or more cultivars were assessed under different levels of $\mathrm{P}$ fertilization (from two to five P levels) (Table 1). In total, eleven cultivars were assessed in the experiments. Five cultivars (Patagonia-INIA, Karu-INIA, Yagana-INIA, Pukara-INIA, Puyehue-INIA, Puren-INIA) created in the INIA potato breeding program since 1980 and three introduced cultivars (Desiree, Spartan, Rodeo and Asterix) (Table 1). Patagonia-INIA, Karu-INIA, Pukara-INIA,
Desiree and Rodeo are popular among potato growers in Chile. Almost all experiments were carried out under rainfed conditions. In experiments where only one cultivar was assessed under different levels of P fertilization, treatments were arranged in a three randomized complete block designs. On the other hand, a split-plot design was used in factorial experiments in which different genotypes and different levels of $\mathrm{P}$ fertilization were assessed, where $P$ rates were assigned to main plots and genotypes to subplots randomized into three blocks.

Table 1. Year, experiments, initial soil Olsen-P, cultivar, water supply and phosphorus rate assessed under field experiments conducted by INIA in southern Chile from 1977 to 2015. In the experiments, different rates of phosphorus fertilization were evaluated, from two to five levels of phosphorus rates.

\begin{tabular}{|c|c|c|c|c|c|c|c|c|c|}
\hline \multirow{2}{*}{$\begin{array}{r}\text { Year } \\
1977\end{array}$} & \multirow{2}{*}{$\begin{array}{l}\text { Experiments } \\
1 \\
1\end{array}$} & \multirow{2}{*}{$\begin{array}{l}\text { Initial Olsen- } \\
\mathrm{P}\left(\mathrm{mg} \mathrm{kg}^{-1}\right) \\
7\end{array}$} & \multirow{2}{*}{$\begin{array}{l}\text { Cultivar } \\
\text { Spartan }\end{array}$} & \multirow{2}{*}{$\begin{array}{l}\text { Water } \\
\text { supply }\end{array}$} & \multicolumn{5}{|c|}{ Phosphorus rates $\left(\mathrm{kg} \mathrm{P} \mathrm{ha}^{-1}\right)$} \\
\hline & & & & & 0 & & 140 & 280 & \\
\hline & 2 & 29 & Spartan & Rainfed & 0 & & 140 & 280 & \\
\hline & 3 & 12 & Spartan & Rainfed & 0 & & 140 & 280 & \\
\hline & 4 & 10 & Desiree & Rainfed & 0 & 65 & 109 & 153 & 196 \\
\hline & 5 & 10 & Spartan & Rainfed & 0 & 116 & 232 & 464 & \\
\hline & 6 & 2 & Spartan & Rainfed & 0 & 87 & 174 & 262 & \\
\hline & 7 & 8 & Spartan & Rainfed & 0 & 116 & 232 & 464 & \\
\hline & 8 & 10 & Spartan & Rainfed & 0 & 116 & 232 & 348 & 464 \\
\hline & 9 & 23 & Spartan & Rainfed & 0 & 140 & 279 & 419 & 559 \\
\hline & 10 & 17 & Spartan & Rainfed & 0 & 65 & 109 & 153 & 196 \\
\hline & 11 & 17 & Ultimus & Rainfed & 0 & 87 & 175 & 350 & \\
\hline \multirow[t]{7}{*}{2008} & 1 & 7.5 & Karu-INIA & Rainfed & 0 & 65 & 130 & 196 & \\
\hline & 2 & 70 & Karu-INIA & Rainfed & 0 & 65 & 130 & 196 & \\
\hline & 3 & 4.3 & Karu-INIA & Rainfed & 0 & 65 & 130 & 196 & \\
\hline & 4 & 12.1 & Karu-INIA & Rainfed & 0 & 65 & 130 & 196 & \\
\hline & 5 & 9.4 & Karu-INIA & Rainfed & 0 & 65 & 130 & 196 & \\
\hline & 6 & 6.6 & Karu-INIA & Rainfed & 0 & 65 & 130 & 196 & \\
\hline & 7 & 10 & Karu-INIA & Rainfed & 0 & 65 & 130 & 196 & \\
\hline \multirow[t]{5}{*}{2009} & 1 & 7.7 & Karu-INIA & Rainfed & 0 & 65 & 130 & 196 & \\
\hline & 2 & 40 & Karu-INIA & Rainfed & 0 & 65 & 130 & 196 & \\
\hline & 3 & 19.5 & Karu-INIA & Rainfed & 0 & 65 & 130 & 196 & \\
\hline & 4 & 94 & Karu-INIA & Rainfed & 0 & 65 & 130 & 196 & \\
\hline & 5 & 10.7 & Karu-INIA & Rainfed & 0 & 65 & 130 & 196 & \\
\hline \multirow[t]{4}{*}{2010} & 1 & 7.5 & Patagonia-INIA & Rainfed & 0 & 65 & 130 & 196 & \\
\hline & 2 & 7.8 & Patagonia-INIA & Rainfed & 0 & 65 & 130 & 196 & \\
\hline & 3 & 12.7 & Patagonia-INIA & Rainfed & 0 & 65 & 130 & 196 & \\
\hline & 4 & 23 & Patagonia-INIA & Rainfed & 0 & 65 & 130 & 196 & \\
\hline \multirow[t]{6}{*}{2011} & 1 & 2.4 & Karu-INIA & Rainfed & 0 & 65 & 130 & 196 & \\
\hline & 2 & 15 & Karu-INIA & Rainfed & 0 & 65 & 130 & 196 & \\
\hline & 3 & 42 & Karu-INIA & Irrigated & 0 & 65 & 130 & 196 & \\
\hline & 4 & 27 & Karu-INIA & Rainfed & 0 & 65 & 130 & 196 & \\
\hline & 5 & 16.2 & Puyehue-INIA & Irrigated & 0 & 65 & & 196 & \\
\hline & 6 & 43 & Karu-INIA & Rainfed & 0 & 65 & & & \\
\hline \multirow[t]{4}{*}{2012} & 1 & 48 & Karu-INIA & Rainfed & 0 & & 130 & 196 & \\
\hline & 2 & 8.2 & 9 cultivars $^{1}$ & Rainfed & 0 & & 130 & & \\
\hline & 3 & 10.7 & 9 cultivars $^{1}$ & Irrigated & 0 & & 130 & & \\
\hline & 4 & 16 & Karu-INIA & Rainfed & 0 & 30 & 74 & 130 & \\
\hline \multirow[t]{2}{*}{2013} & 1 & 7.2 & 9 cultivars $^{1}$ & Rainfed & 0 & & 130 & & \\
\hline & 2 & 7.3 & 3 cultivars $^{2}$ & Irrigated & 0 & & 130 & & \\
\hline \multirow[t]{2}{*}{2015} & 1 & 6.3 & Patagonia-INIA & Rainfed & 0 & & 130 & & \\
\hline & 2 & 4 & Patagonia-INIA & Rainfed & 0 & 65 & & 196 & \\
\hline
\end{tabular}

Desiree, Patagonia-INIA, Karu-INIA, Yagana-INIA, Pukara-INIA, Puyehue-INIA, Puren-INIA, Rodeo and Asterix. ${ }^{2}$ Patagonia-INIA, Rodeo and Asterix. 


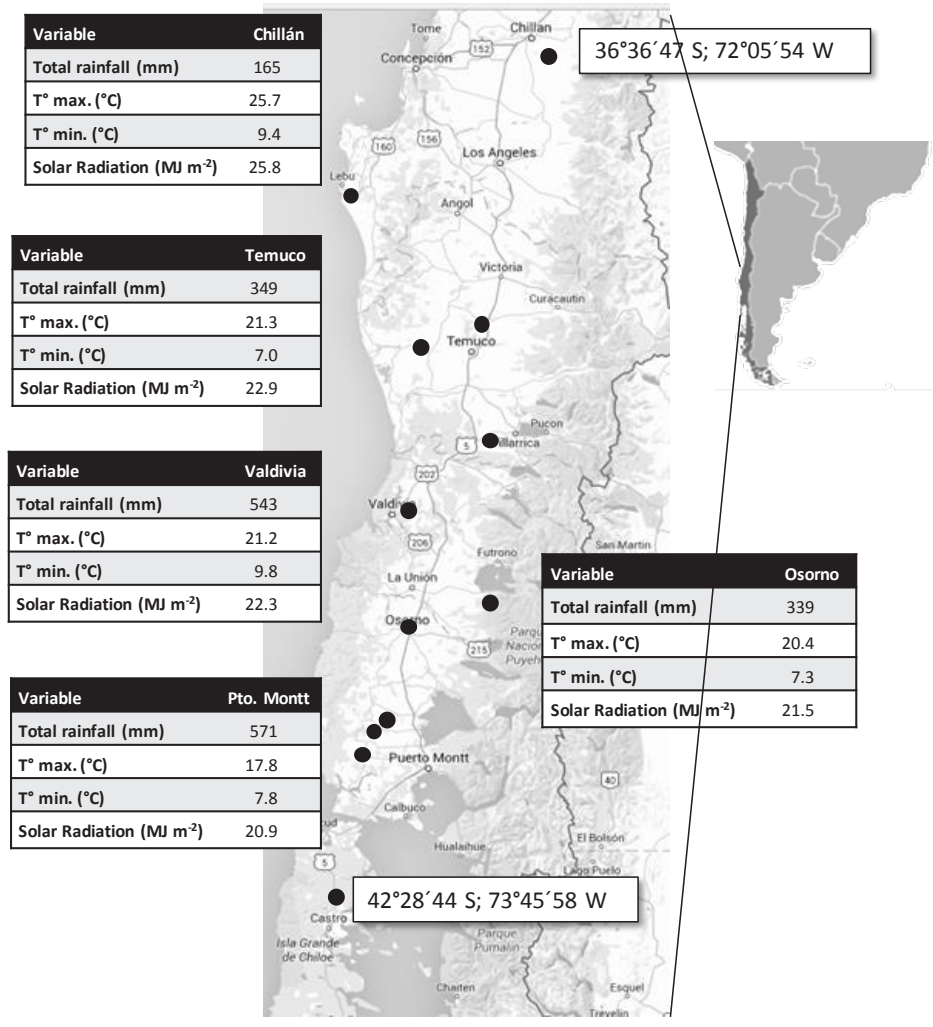

Figure 1. Site distribution of experiments and average historical rainfall, maximum (T max.) and minimum ( $\mathrm{T}$ min.) temperatures and incident solar radiation during the period October-March in five locations in southern Chile.

In general, in all experiments soils had high acidity (on average $5.5 \mathrm{pH}$ in water), high organic matter content (on average 14.4\%) and moderate to low $\mathrm{P}$ availability for potato production. Across experiments, the initial soil Olsen-P level (Olsen et al., 1954) (20 cm depth) ranged between 2 and $70 \mathrm{mg}$ Olsen-P kg-1 (Table 1). Olsen-P has been shown to extract an amount of $\mathrm{P}$ that is representative of the phosphate released into the solution and taken up by the plants.

\subsection{Crop culture and measurements}

Each experimental plot consisted of 4 rows $5.6 \mathrm{~m}$ long placed $0.75 \mathrm{~m}$ apart. The planting density was 40,000 potato seeds $\mathrm{ha}^{-1}$. Experiments received the same amount per hectare of $\mathrm{N}, \mathrm{K}, \mathrm{Mg}$ and $\mathrm{Ca}(150 \mathrm{~kg} \mathrm{~N}, 87$ $\mathrm{kg} \mathrm{K}, 22 \mathrm{~kg} \mathrm{Mg}$ and $37 \mathrm{~kg} \mathrm{Ca}$ ). These nutrients plus the corresponding $\mathrm{P}$ fertilization rates were incorporated into each row by hand at planting. The fertilizer sources for N, P and K were Nitromag (27\% N, 3\% 
$\mathrm{Mg}$ and 5\% Ca), Triple Super Phosphate (20\% P), and Potassium chloride $(\mathrm{KCl})(31 \% \mathrm{~K})$, respectively. The experiments were maintained free of biotic stresses. Thus, weeds, diseases and insects were prevented with the use of pesticides at the rates recommended by their manufacturers.

At harvest, fresh tuber yield was determined in each plot from two central rows $5 \mathrm{~m}$ long $\left(7.5 \mathrm{~m}^{2}\right)$ without edge effects. To eliminate the variability among years, sites and cultivars, the relative yields (RY) were calculated as (Bai et al., 2013):

$R Y: Y_{0} / Y_{m}$

Where $\mathrm{Y}_{0}$ is the yield of treatments with no P fertilization and $Y_{m}$ is the maximum yield obtained in the field trial during the same year with the best treatment fertilized with $P$.

In order to identify the critical values of soil Olsen$\mathrm{P}$, the relationship between $\mathrm{RY}$ in response to initial soil P-Olsen (mg Olsen-P $\mathrm{kg}^{-1}$ ) was assessed by using three models (linear-plateau, boundary and Mitscherlich function).

The linear-plateau model was defined by Equations 1 and 2 :

$$
\begin{array}{lll}
R Y=a+b x, \text { if }(x<c) & \text { Equation 1 } \\
R Y=P, & \text { if }(x \geq c) & \text { Equation 2 }
\end{array}
$$

where $R Y$ is the relative yield, $a$ is the intercept, $b$ is the slope, and $c$ is the critical Olsen-P value (mg Olsen- $\mathrm{P} \mathrm{kg}^{-1}$ ) and $\mathrm{P}$ is the predicted relative plateau yield.

The boundary function was defined by the Equation (3):

$R Y=a+b x$

Equation 3 where RY is the relative yield, $a$ is the intercept, $b$ is the slope and $\mathrm{X}$ is the initial concentration of soil Olsen-P ( $\mathrm{mg} \mathrm{P} \mathrm{kg}^{-1}$ ). This function was fitted only to the $15 \%$ lowest relative yields observed across experiments. The critical Olsen-P value was considered as the intercept of this function with the horizontal line showing the $\mathrm{RY}=1$.

The Mitscherlich model is given by Equation 4:

$R Y=A *\left(1-e^{(-c x)}\right)$

Equation 4

where $\mathrm{RY}$ is the relative yield, $A$ is the maximum attainable $\mathrm{RY}$ when $\mathrm{X}$ is not limiting, $c$ is a response factor and $\mathrm{x}$ is the concentration of soil Olsen-P. The critical value of Olsen-P was calculated following Tang et al. (2009) based on the Olsen-P value corresponding to $90 \%$ of maximum predicted relative yield (A).

\subsection{Statistical analyses}

In each experiment, an analysis of variance (ANOVA) was used to assess the effects of $P$ treatments on fresh tuber yield. This was performed with the software Statistica 7.0. The linear-plateau and boundary regressions were performed using a routine TBL curve (Jandel Scientific). The Mistcherlich model was performed using the software SigmaPlot v.13. A least significant differences (LSD) test was calculated at $5 \%$ significance for mean comparison. Linear regression analyses and ANOVA were also performed with Statistica 7.0.

\section{Results}

Across experiments, the average fresh tuber yield was $41.9 \mathrm{Mg} \mathrm{ha}^{-1}$ and varied between 4 and $89 \mathrm{Mg} \mathrm{ha}^{-1}$, following a normal distribution (Figure 2a). Fresh tuber yield decreased up to $92 \%$ under no P fertilization; however, yield reduction was concentrated between 
20 and $40 \%$ in response to $\mathrm{P}$ deficiency (Figure 2b).

The relationship between relative yield and initial soil Olsen-P content showed that, across all experiments, significant yield reductions were observed with soil Olsen-P values below $30 \mathrm{mg}$ P-Olsen $\mathrm{kg}^{-1}$ (Figure 3$)$. Relative yield was significantly $(P<$ 0.01 ) related to initial soil Olsen-P when described by the linear-plateau and Mitscherlich models. However, the coefficient of determinations of these models were lower $\left(\mathrm{R}^{2}=0.23-0.31\right)$ owing to the scatter of data below the $30 \mathrm{mg}$ Olsen- $\mathrm{P} \mathrm{kg}^{-1}$ (Figure 3) than the boundary function fitted to the lowest relative yields observed across experiments was significant $\left(P<0.05 ; \mathrm{R}^{2}=0.97\right)$. The three models used made it possible to identify three critical values of soil Olsen-P for potato production. The critical values were 41, 33 and $11 \mathrm{mg}$ Olsen$\mathrm{P} \mathrm{kg}^{-1}$ using the linear-plateau, boundary function and Mitscherlich model, respectively (Figure 3). However, the linear-plateau and Mitscherlich functions are less suitable than the boundary function because they do not take into account the lower relative yields observed. In addition, the Mitscherlich model underestimates the maximum attainable relative yield by around $20 \%$.
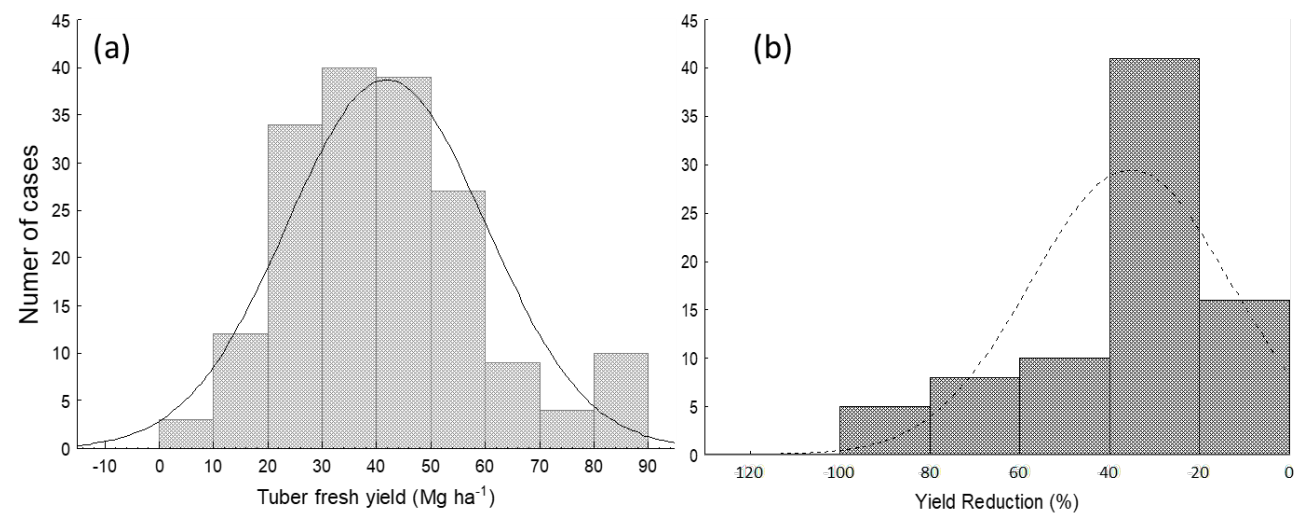

Figure 2. Frequency distribution of fresh tuber yield observed in all treatments across experiments (a) and frequency distribution of yield reduction in treatments with no $\mathrm{P}$ application (b). 


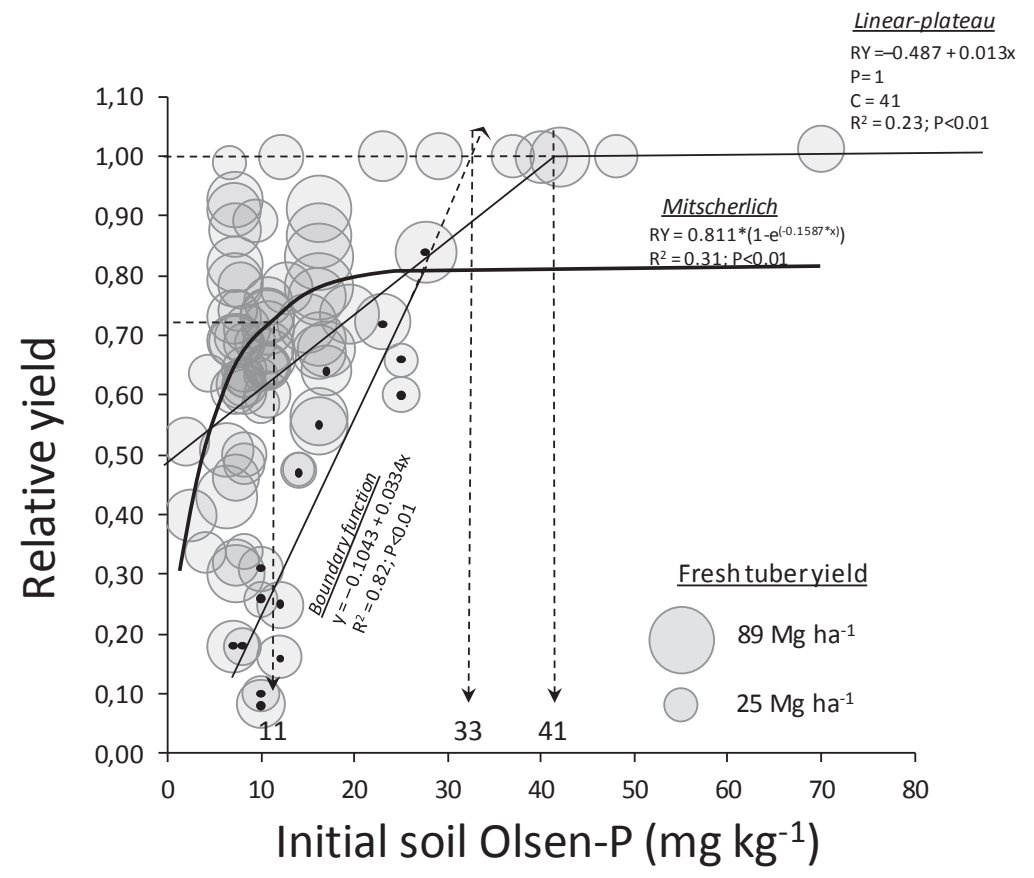

Figure 3. Relationship between relative fresh tuber yield and initial soil Olsen-P content of each experiment fitted with the Mitscherlich, linear-plateau and boundary models. Boundary regression was fitted to the $15 \%$ lowest relative yields observed (circles with black dots). The size of the circles indicate the maximum yield observed under the highest $\mathrm{P}$ fertilization treatments. Arrows indicate the critical value of soil Olsen-P determined with each model.

\section{Discussion}

A critical Olsen-P value can be defined as "a soil $\mathrm{P}$ status above which crop yield does not respond to $\mathrm{P}$ fertilization" (Tang et al., 2009; Bai et al., 2013; Xi et at., 2016; Sucunza et al., 2018). Variation in critical levels may stem from different models that have been used to estimate critical levels (Bai et al., 2013). In the present study, different critical Olsen-P values (11, 33 and $41 \mathrm{mg} \mathrm{P} \mathrm{kg}^{-1}$ ) were identified depending on the model used. This is in agreement with previous studies, in which different models were used to assess the yield response of different crops to soil P availability (Tang et al., 2009; Sucunza et al., 2018). Our results suggest that a critical Olsen-P value of 33 is less risky for potato growers than the critical values determined with the other models. Therefore, in order to reduce $P$ accumulation in the soil and the risk of $P$ for the environment, potato crops in volcanic soils with Olsen-P levels below or above the critical values reported in the present study (averaged $33 \mathrm{mg} \mathrm{P} \mathrm{kg}^{-1}$ ) will require corrections and maintenance fertilization rates (i.e.: the exported $\mathrm{P}$ from the field in product harvested), respectively. 
Our critical Olsen-P value is higher than those previously reported. Previous studies have reported a critical value of Olsen-P for potato of 15 (Recke et al., 1997), 17 (Maier et al., 1989), 25-26 (Johnston et al., 1986; Johnston et al., 2013) and 27 mg P kg-1 (Freeman et al., 1998). However, Johnston et al. (1986) concluded that potato yield generally plateaued when the soil Olsen-P test reached $25 \mathrm{mg} \mathrm{P} \mathrm{kg}^{-1}$, but the value varied between 10 and $54 \mathrm{mg} \mathrm{P} \mathrm{kg}^{-1}$ across years. Differences in the critical Olsen-P level may be also affected by differences in soil properties such as soil type, soil structure, $\mathrm{pH}$ and organic matter (Bai et al., 2013; Johnston et al., 2013; Poulton et al., 2013). Freeman et al. (1998) stated that their higher critical Olsen-P value compared to the critical value reported by Maier et al. (1989) reflects the higher clay content of the krasnozem and duplex soils. Our results are in line with the Freeman et al. (1998) report (Figure 4), since the clay and silt content of Andisol soils are much higher than the sandy soil assessed by Maier et al. (1989), with 5698\% of sand content. From Figure 4 it is evident that sandy soils have lower critical Olsen-P values than soils with a high clay content such as those of Freeman et al. (1998) and soils of the present study. However, some of these differences could be also attributed to differences in soil sampling depth since, compared with our sampling depth (0$20 \mathrm{~cm}$ ), in the study by Maier et al. (1989) and Freeman et al. (1998) the sampling depth was 0-15 and $0-10 \mathrm{~cm}$, respectively.

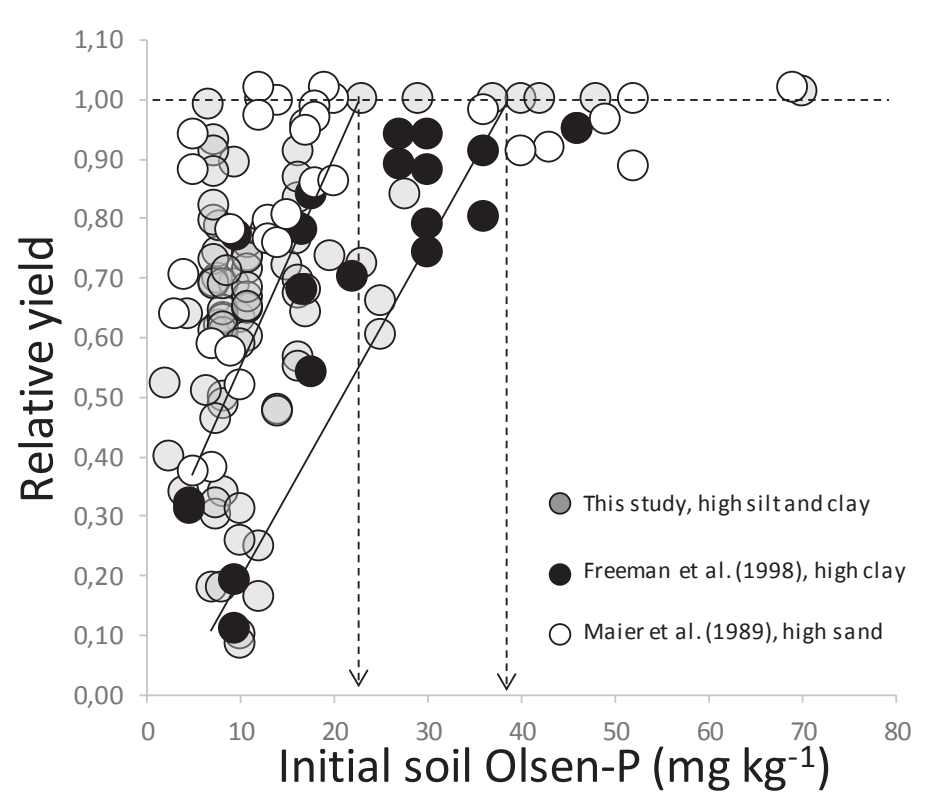

Figure 4. Relationship between relative tuber yield and soil Olsen-P content in the studies by Maier et al. (1989) (white circles), Freeman et al. (1998) (black circles) and this study (grey circles). Boundary function was fitted by eye. Arrows indicate different critical values of soil Olsen-P depending on sand or clay soil content. 
Critical Olsen-P values may differ among years and cultivars. In the present study, different genotypes were included to assess the critical Olsen-P value. Previous studies in potato have shown important genotypic differences in P uptake efficiency (Soratto et al., 2015; Sandaña, 2016). This implies that the relationship between relative yield and soil Olsen-P and, as a result the critical Olsen-P value, can be affected by the genotype. This was observed in the study by Freeman et al. (1998), in which the yield deficit was greater for cv. Russet Burbank than for cv. Kennebec for Olsen-P concentrations higher than $10 \mathrm{mg} \mathrm{kg}$ 1. The cultivar effects on critical Olsen-P, however, seem to be much lower than the effect of the soil type, since Maier et al. (1989) found from experiments at 33 sites that the critical soil $\mathrm{P}$ concentration ranges for various cultivars were not significantly different overall. On the other hand, critical Olsen-P values may differ due to seasonal variation in weather conditions, mainly rainfall (Johnston et al., 2013; Poulton et al., 2013). This can affect the growth and yield responses of potato crops for the same initial level of Olsen-P (e.g.: Figure 3).

\section{Conclusions}

The present study, across different experiments, demonstrated that the critical value of soil Olsen-P was better determinate by the boundary function model, with a critical value of $33 \mathrm{mg} \mathrm{P} \mathrm{kg}^{-1}$ for soils with high $\mathrm{P}$ fixing capacity. This value is less risky for potato growers than the critical value determined with the linear-plateau and Mitscherlich models. To maintain this critical value over time, the $\mathrm{P}$ removed in the product harvested from the field should be replaced through equivalent rates of $\mathrm{P}$ fertilization. This information will be useful for local potato growers, cropping in volcanic soils such as Andisols, to increase P use efficiency by reducing $\mathrm{P}$ inputs, excess $\mathrm{P}$ accumulation in soils and potential risks of water contamination.

\section{Acknowledgements}

This work comprised several years of field assessments and the authors thank the many different members of staff who helped with the field experiments. The authors also gratefully acknowledge financial support from Project FIA "Consorcio Tecnológico de la Papa" and Project CONICYT/FONDECYT/INICIACION/ ${ }^{\circ} 11121190$. The revision of English usage by Helen Lowry is greatly appreciated.

\section{References}

Bai, Z., Li, H., Yang, X., Zhou, B., Shi, X., Wang, B., Li, D., Shen, J., Chen, Q., Qin, W., Oenema, O., Zhang, F. 2013. The critical soil P levels for crop yield, soil fertility and environmental safety in different soil types. Plant Soil. 372, 27-37.

Balemi, T., Negisho, K. 2012. Management of soil phosphorus and plant adaptation mechanisms to phosphorus stress for sustainable crop production: a review. J. Soil Sci. Plant Nutr. 12, 547-561.

Bollons. H.M., Barraclough, P.B. 1999. Assessing the phosphorus status of winter wheat crops: inorganic orthophosphate in whole shoots. J. Agric. Sci. 133, 285-295.

Colomb, B., Debaeke, P., Jouany, C., Nolot, J.M. 2007. Phosphorus management in low input stockless cropping systems: Crop and soil responses to contrasting P regimes in a 36-year experiment in southern France. Eur. J. Agron. 26, 154-165.

Cordell, D., Drangert, J.-O., White, S. 2009. The story of phosphorus: Global food security and food for thought. Global Environ. Chan. 19, 292-305.

Dahlgren, R., Saigusa, M., Ugolini. F. 2004. Nature, properties and management of volcanic soils. Advn. Agron. 82, 113-181. 
Elser, J., Bennett, E. 2011. Phosphorus cycle: A broken biogeochemical cycle. Nature. 478, 29-31.

Freeman, K.L., Franz, P.R., de Jong, R.W. 1998. Effect of phosphorus on the yield, quality and petiolar phosphorus concentrations of potatoes (cvv. Russet Burbank and Kennebec) grown in the krasnozem and duplex soils of Victoria. Aust. J. Exp. Agric. 38, 83-93.

Gregory, P.J., George, T.S. 2011. Feeding nine billion: the challenge to sustainable crop production. J. Exp. Bot. 62, 5233-5239.

Haverkort, A.J., Sandaña, P., Kalazich, J. 2014. Yield gaps and ecological footprints of potato production systems in chile. Potato Res. 57, 13-31.

Hopkins, B.G., Horneck, D.A., MacGuidwin, A.E. 2014. Improving Phosphorus Use Efficiency Through Potato Rhizosphere Modification and Extension. Am. J. Potato Res. 91, 161-174.

Johnston, A.E., Lane, P.W., Mattingly, G.E.G., Poulton, P.R., Hewitt, M.V. 1986. Effects of soil and fertilizer $P$ on yields of potatoes, sugar beer, barley and winter wheat on a sandy clay loam soil at Sazmundham, Suffolk. J. Agric. Sci. 106, 155167.

Johnston, A.E., Poulton, P.R., White, R.P. 2013. Plantavailable soil phosphorus. Part II: the response of arable crops to Olsen $\mathrm{P}$ on a sandy clay loam and a silty clay loam. Soil Use Manag. 29, 12-21.

Maier, N., Potocky-Pacay, K., Jacka, J., Williams, C. 1989. Effect of phosphorus fertiliser on the yield of potato tubers (Solanum tuberosum L.) and the prediction of tuber yield response by soil analysis. Aust. J. Exp. Agric. 29, 419-431.

Mallarino, A.P., Atia, A.M. 2005. Correlation of a resin membrane soil phosphorus test with corn yield and routine soil tests. Soil Sci. Soc. Am. J. 69, 266-272.
Manske, G., Ortiz-Monasterio, J., Van Ginkel, M., González, R., Fischer, R., Rajaram, S., Vlek, P. 2001. Importance of uptake efficiency versus $P$ utilization for wheat yield in acid and calcareous soils in Mexico. Eur. J. Agron. 14, 261-274.

ODEPA. 2017. Estadísticas productivas. Excel file in: https://www.odepa.gob.cl/estadisticas-del-sector/ estadisticas-productivas

Olsen, S.R., Cole, C.V., Watanabe, F.S., Dean, L.A. 1954. Estimation of available phosphorus in soils by extraction with sodium bicarbonate. USDA Circular N0. 939. US Govt. Print. Office, Washington, DC

Poulton, P.R., Johnston, A.E., White, R.P. 2013. Plantavailable soil phosphorus. Part I: the response of winter wheat and spring barley to Olsen $\mathrm{P}$ on a silty clay loam. Soil Use Manag. 29, 4-11.

Recke, H., Schnier, H.F., Nabwile, S., Qureshi, J.N. 1997. Responses of Irish potatoes (Solanum tuberosum L.) to mineral and organic fertilizer in various agro-ecological encironments in Kenya. Expl. Agric. 33, 91-102.

Redulla, C.A., Davenport, J.R., Evans, R.G., Hattendorf, M.J., Alva, A.K., Boydston, R.A. 2002. Relating potato yield and quality to field scale variability in soil characteristics. Am. J. Potato Res.79, 317-323.

Rosen, C.J., Kelling, K.A., Stark, J.C., Porter, G.A. 2014. Optimizing Phosphorus Fertilizer Management in Potato Production. Am. J. Potato Res. 91, 145-160.

Rowe, H., Withers, P.J.A., Baas, P., Chan, N.I., Doody, D., Holiman, J., Jacobs, B., Li, H., MacDonald, G.K., McDowell, R., Sharpley, A.N., Shen, J., Taheri, W., Wallenstein, M., Weintraub, M.N. 2016. Integrating legacy soil phosphorus into sustainable nutrient management strategies for future food, bioenergy and water security. Nutr. Cycl. Agroecosystems. 104, 393-412. 
Sandaña, P., Kalazich, J. 2015. Ecophysiological determinants of tuber yield as affected by potato genotype and phosphorus availability. Field Crops Res. 180, 21-28.

Sandaña, P. 2016. Phosphorus Uptake and Utilization Efficiency in Response to Potato Genotype and Phosphorus Availability. Eur. J. Agron. 76, 95-106.

Sandaña, P., Pinochet, D., 2014. Grain yield and phosphorus use efficiency of wheat and pea in a high yielding environment. J. Soil Sci. Plant Nutr. 14, 973-986.

Sandaña, P., Pinochet, D. 2016. Phosphorus acquisition of wheat, pea and narrow-leafed lupin under different P supplies. J. Soil Sci. Plant Nutr. 16, 537-549.

Soratto, R.P., Pilon, C., Fernandes, A.M., Moreno, L.A. 2015. Phosphorus uptake, use efficiency, and response of potato cultivars to phosphorus levels. Potato Res. 58, 121-134.

Sucunza, F., Gutierrez, H.H., García, F., Boxler, M., Rubio, G. 2018. Long-term phosphorus fertilization of wheat, soybean and maize on Mollisols: Soil test trend, critical levels and balances. Eur. J. Agron. 96, 87-95.
Tang, X., Ma, Y., Hao, X., Li, X., Li, J., Huang, S., Yang, X., 2009. Determining critical values of soil Olsen-P for maize and winter wheat from long-term experiments in China. Plant Soil. 323, 143-151.

Thornton, M.K., Novy, R.G., Stark, J.C. 2014. Improving phosphorus use efficiency in the future. Am. J. Potato Res. 91, 175-179.

Tilman, D., Fargione, J., Wolff, B., D’Antonio, C., Dobson, A., Howarth, R., Schindler, D., Schlesinger, W.H., Simberloff, D., Swackhamer, D. 2001. Forecasting agriculturally driven global environmental change. Science. 292, 281-284.

Tilman, D., Cassman, K.G., Matson, P.A., Naylor, R., Polasky, S. 2002. Agricultural sustainability and intensive production practices. Nature. 418 , 671-677.

Valle, S.R., Carrasco, J., Pinochet, D., Soto, P., Donald, R.M. 2015. Spatial distribution assessment of extractable $\mathrm{Al},(\mathrm{NaF}) \mathrm{pH}$ and phosphate retention as tests to differentiate among volcanic soils. Catena. $127,17-25$.

Xi, Bin, Zhai, L., Liu, J., Shen, L., Wang, H.-Y., Luo, C.-Y., Ren T-Z., Liu, H-B. 2016. Long-term phosphorus accumulation and agronomic and environmental critical phosphorus levels in Haplic Luvisol soil, northern China. J. Integr. Agric. 15, 200-208. 
